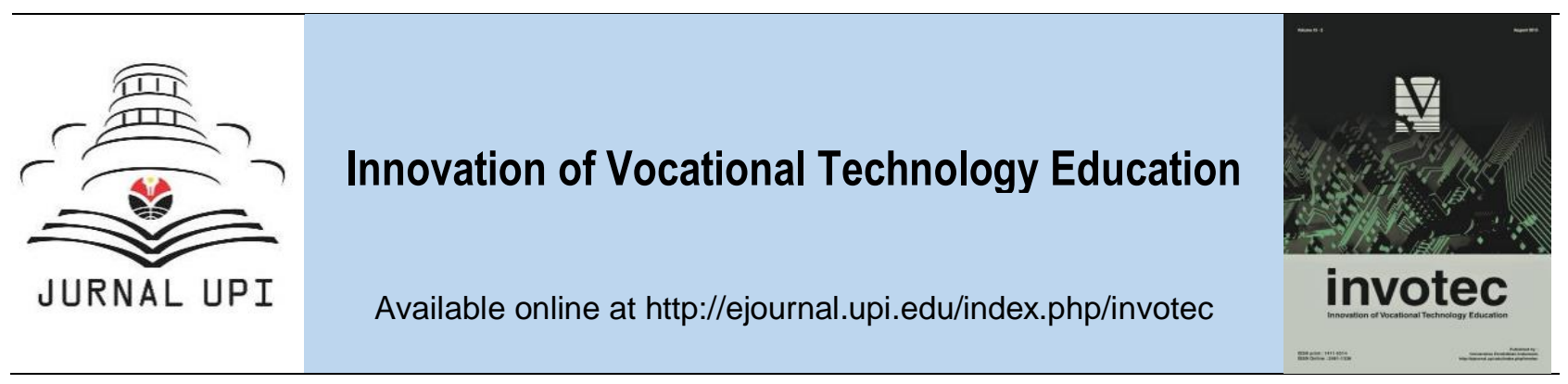

\title{
VOCATIONAL EDUCATION: ASSESSMENT, CLASSIFICATION AND THE REALM OF RESEARCH DEVELOPMENTS
}

\author{
I. Widianingsih, I.M. Purwaamijaya, V. Dwiyanti \\ Universitas Pendidikan Indonesia, Indonesia
}

\section{ARTICLE INFO}

Article history:

Received 31 May 2018

Received in revised form 29 June 2018

Accepted 31 July 2018

Available online 31 August 2018

Keywords:

assessment vocational education

aspects of the research

trend research

Corresponding author:

irmaw@upi.edu

\begin{abstract}
Education is one of the most important things to prepare for the competitive human resources in achieving success in the era of globalization. The main source of the success of the national development of a country is the development of human resources. Vocational education is expected to be one form of education that is able to develop human resources. Vocational education is an education that prepares students to work in a particular field.This article aims to examine the aspect and sphere of research related to vocational education. The method used is the study of literature relating to research on vocational education as well as an analysis of several publications. The results show that there is a wide range of topics related to vocational training, ranging from models of learning, instructional media, graduate competence, motivation, teacher performance, the role of industry to the development of vocational education, teaching materials of vocational education, information systems education, curriculum development of vocational education, policy government and stakeholders for the development of vocational education.
\end{abstract}

\section{Introduction}

Education is one of the most important things to prepare for the competitive human resources in achieving success in the era of globalization (Mortaki, 2012). Education is the main pillar for the advancement of a nation. Education must be a priority for development, with no prejudice to other sectors (Kasnar and Santoso, 2009). To promote education not only by changing the curriculum and complementary facilities and infrastructure, but also pay attention to the development of human resources will also assume such education. Therefore, to achieve a better education in the future, which is a top priority for this is the improvement of human resources (HR) through quality education and evenly distributed throughout the population, and the main thing is to raise awareness for all elements of society and the government and the parties concerned to improve itself (Kharistiani and Ariwibowo, 2013).

The world of education has progressed over time. Education world has now entered the highlevel technological advances, especially in the field of information and communication. System education required to tune with advances in information technology and communication (Asnawi and Djatmiko, 2015). The main source of the success of the national development of a country is the development of human resources (Kharistiani and Ariwibowo, 2013). Vocational education is expected to be one form of education that is able to develop human resources. Vocational education 
is an education that prepares students to work in a particular field (Kasnar and Santoso, 2009). Vocational education is one of the sub-system of the national education system that prepares graduates to enter the workforce and fill mid-level skilled manpower needs (Fuller, 2015). Vocational education plays an important role in the socio economic development of a region (Poryono, 2013). Vocational education is very strategic role in sustaining economic growth and competitiveness of the nation's progress. Strategic planning for vocational education needs to be structured so that the progress of vocational education and its role in improving the quality and relevance in the field of education can be monitored and evaluated with measurable (Agrawal, 2013).

National vocational education system has shown some important dimensions that can be distinguished and some implications for social justice and inclusion and for education and career advancement (Fuller, 2015). 3 approaches to make the conceptualization of vocational education, namely: human capital approach, the approach of sustainable development and social justice approach (Tykli, 2015). Vocational education systems in some countries ASIA playing a significant role in the public eye. Implementation of the development of vocational education is still based on the assumption of society with education and programs that are the trend (Agrawal, 2013). Vocational education should include teaching the theory and practice are balanced. Business courses must cooperate with the professional community in the field (Wijanarka, 2014),

Historical development of vocational education is long enough started in 2000 BC. Originally just a vocational education program organized internship. Then evolved into a study program in the classroom and in the workplace (Wijanarka, 2014). In Indonesia, the history of vocational education begins before independence, the beginning of independence, the new order and order reforms. Schools vocational education in Indonesia started from the establishment of the school pertukanngan School Ambacht van Soerabaja 1853 by private parties. In 1856, the Dutch government established a similar school in Jakarta with Leergang Ambacht name, then in 1901 was followed by the opening of educational institutions named Koningin Welhelmina School. Ambacht Leergang prepare workers artisan, Ambacht School provides higher training and technische school provide higher training and theoretical.

Table 1. Historical development of vocational education in Indonesia

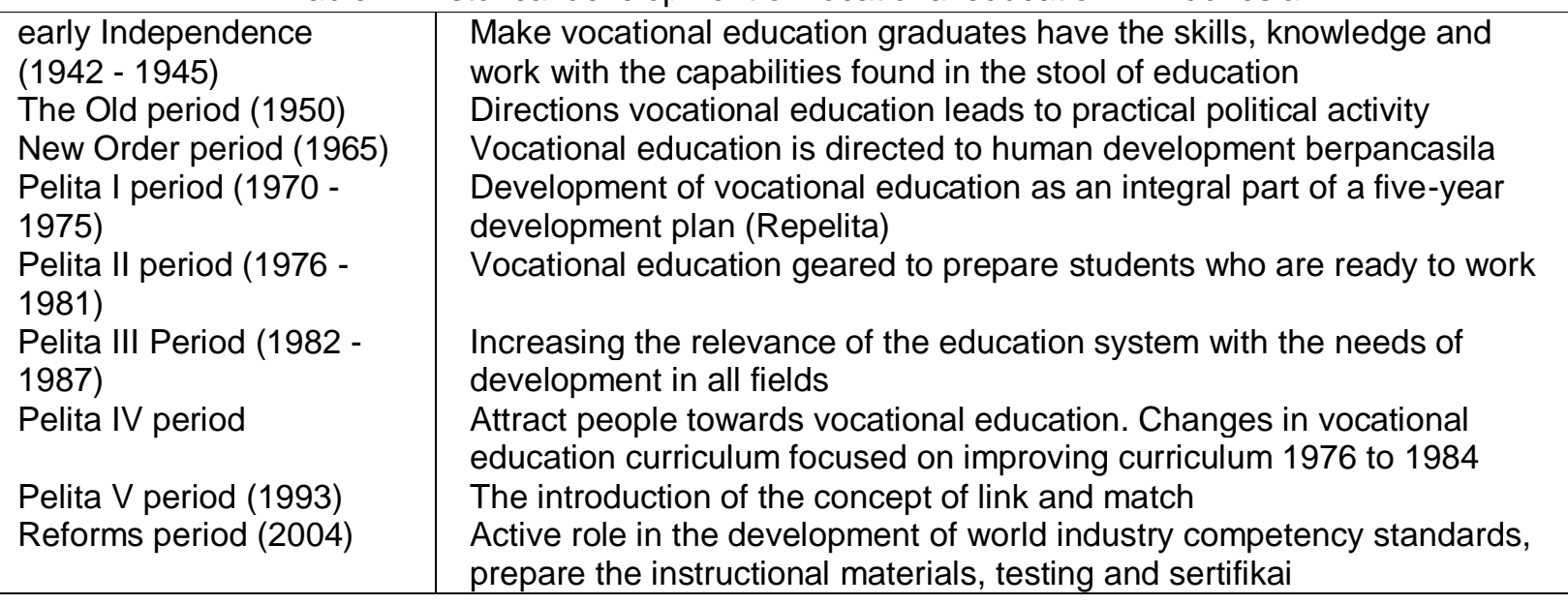

Vocational education to teach the concept of practical skills/functional to prepare the workforce. Vocational education is an educational concept that combines theoretical knowledge, conceptual understanding, talents, creative abilities, physical skills reproductive ability to prepare the workforce (Djatmiko, 2013). Characteristics of Technology Education and Vocational could be seen from several aspects, among which: a) the purpose of vocational education is to prepare graduates to enter the world of work, b) the material being taught is the knowledge and skills for the world of work, c) group served are students who are ready to work on specific areas, d) learning method uses experience to develop thinking skills and the performance on the job and e) familiarize practice to achieve the learning objectives.

There are seven characteristics of vocational education that differentiates it from other educational (Djohar, 2007), among which: a) vocational education is an education that prepares workers, b) vocational education based on the needs of the workforce c) learning materials 
technology education and vocational include domains domain affective, cognitive and psychomotor applied either on the employment situation simulated through the learning process, and the situation of the actual work, $d$ ) the success of vocational education is measured by two criteria, namely the success of students in school (in-school success), and student success outside of school (out-of school success). The first criterion includes student success in meeting the curricular requirements, whereas the second criteria is indicated by the success or graduate appearance after being in the real world of work, e) vocational education has a sensitivity/power (responsiveness) to the development of the world of work. Therefore, vocational education must be responsive and proactive to the development of science and technology, with an emphasis on the efforts of adaptability and flexibility to meet the career prospects of the students in the long term, $f$ ) workshops and laboratories is the completeness major in vocational education, in order to realize the situation learn to reflect the situation in a realistic world of work and educational and $\mathrm{g}$ ) the relationship of cooperation between vocational institutions with business and industry is a necessity.

Meanwhile, the characteristics of technology education and vocational are: a) the orientation of vocational education as an education system that aims to prepare its graduates enter the workforce, then the orientation of vocational education should be focused on the success of learning in the form of output or graduates that can be marketed on the market labor (Paryono, 2013). Furthermore the success of vocational education program completely oriented to the future performance of their graduates in employment, b) the justification for its existence to develop vocational education programs need a special reason or justification is not so perceived by the public education. Special justification is that there is a real need felt workforce in employment or in both goods and services industries, c) focus on vocational education curriculum not only emphasizes the skill aspects of the material, but also emphasize the other aspects of learning. Stimulation and learning experiences that are presented through vocational education include stimulation and learning experiences that develop domain affective, cognitive and psychomotor following integral alloys that are ready to be integrated well in a simulated work situations through the learning process and later in actual work situations. This includes working attitude and orientation of the underlying value of the aspirations, motivation and ability to work, d) the criteria of success in contrast to general education, the criteria for determining the success of a vocational institution basically applying two criteria: success in school (in school success) and out of school success. The first criteria include aspects of student success in meeting the curricular requirements already oriented to the requirements of the working world, while criteria which both indicated by the success or performance of graduates after being in the real world of work, e) susceptibility to the development of society as a strong commitment to always be oriented to the world of work, vocational education possessed other characteristics such as sensitivity or custom high power to the development of society and the world of work. The development of science and technology world ebb and flow of a field of work, innovation and new discoveries in the field of production of goods and services, everything was very big influence on the development trend of vocational education, f) logistical supplies in terms of learning tools, then to realize a situation or a learning experience that can reflect the world situation realistically and educative work required a lot of equipment, facilities and other logistical supplies. Workshops and laboratories are common completeness that accompanies the existence of a vocational school. This makes creating vocational schools cost much more than the public schools, g) relationship with the business community/world industry further relationship with the community that includes carrying capacity and absorption of the environment is very important role for the life and death of an institution vocational education. Embodiments of the interrelationships that support their advisory board include vocational curriculum (curriculum advisory committee).

\section{Method}

The method used in this article is the study of literature gathered from several sources related to vocational education publications. Articles were collected from 2007 to 2016 . For more details of the methods in the writing of this article is presented in Figure 1. 


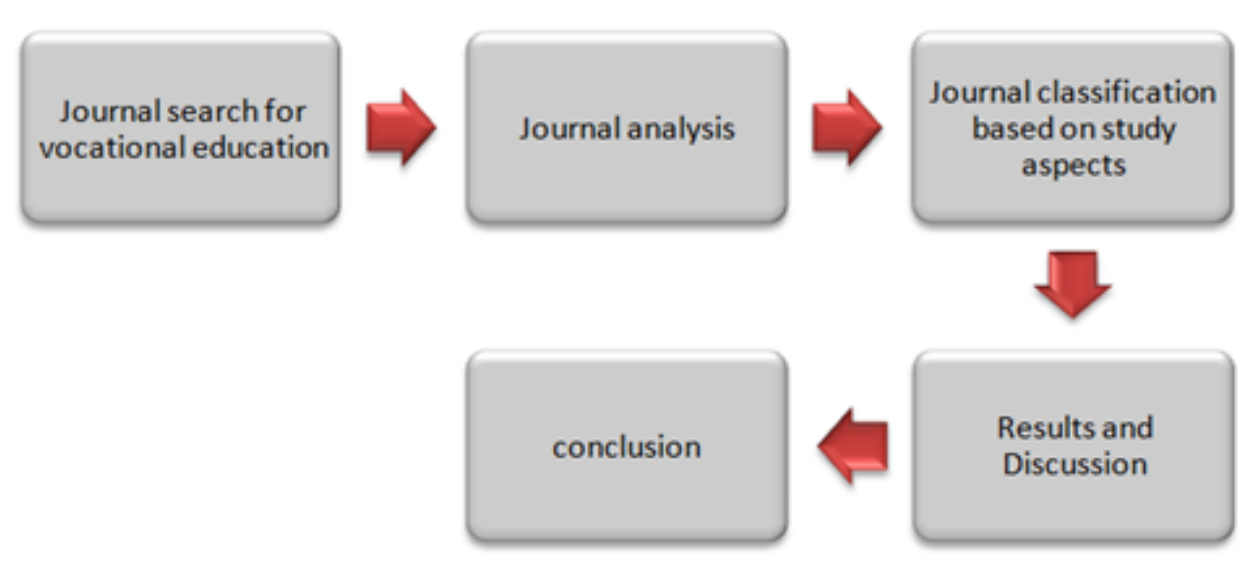

Figure 1. Flow Methods

The steps undertaken in preparation of this article are: 1) search by keyword journal vocational education. Searches are conducted online from the site direct science, google shoolar, Sinta, sagepub etc. The articles obtained as many as 341 articles a combination of various sources of search, 2) journals have been collected and analyzed based on aspects of the study were examined, using the application Microsoft Excel 3) classification of journals based on aspects of studies related to vocational education, 4) articles that were analyzed and classified then discussed and finally concluded.

\section{Results and Discussion}

Research often in technology and vocational education is a quantitative research. The research field of technical and vocational education undergone several changes (Yasin et al., 2013). Search articles on vocational education amounted to 341 articles. The results show that there is a wide range of topics related to vocational training, ranging from models of learning, instructional media, graduate competence, motivation, teacher performance, the role of industry to the development of vocational education, teaching materials of vocational education, information systems education, curriculum development of vocational education, policy government and stakeholders for the development of vocational education and others (Figure 2).

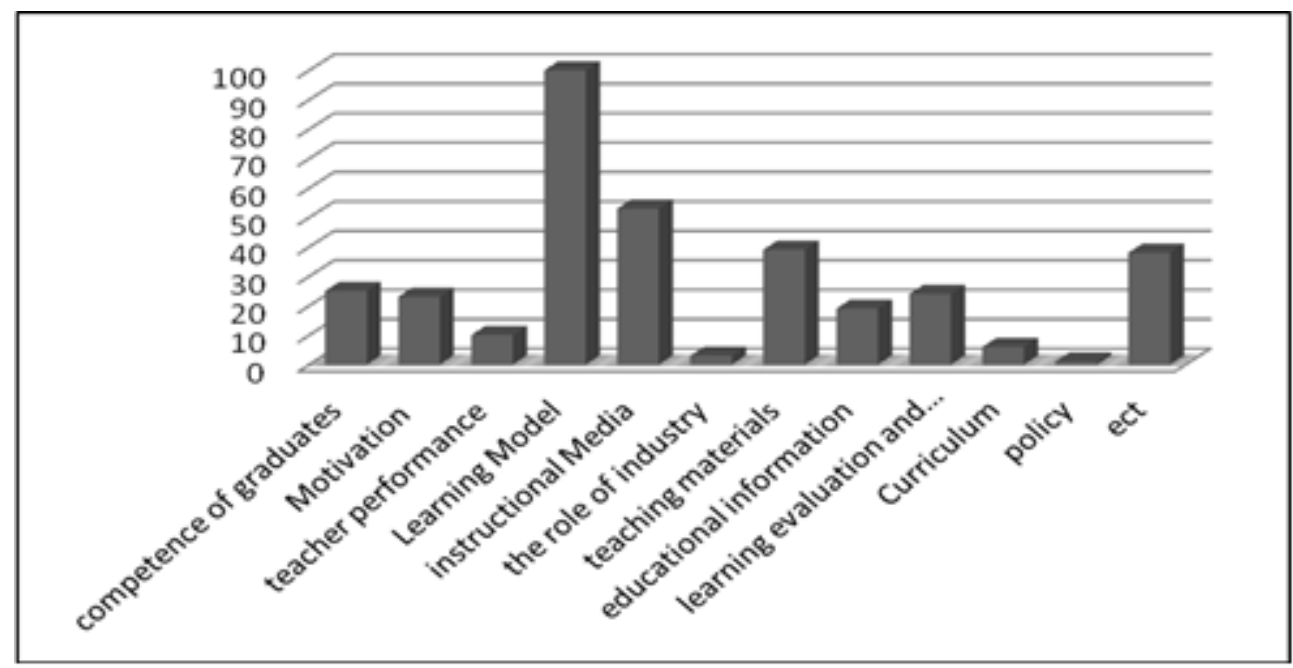

Figure 2. Graph Analysis Journal

Based on the analysis and classification of the journals that have been collected showed that the sphere of research related to vocational education more dominated by the learning model with 100 articles, and instructional media 53 articles, materials 39 articles, other studies but still related to education vocational 38 articles, 25 articles of competency, assessment and evaluation of learning 24 articles, 23 articles learning motivation, education information 19 articles, 10 articles of teacher 
performance, curriculum 6 article, the role of industry for vocational education and policy 3 article 1 of the article.

Distribution of the research that has been conducted shows that research related to the development of the learning model of vocational education more to do with the amount of percentage of $29 \%$, development of instructional media vocational education $16 \%$, development of teaching materials by $11 \%$, other studies are still associated with vocational education at $11 \%$, the absorption of the competence of graduates of vocational education by $7 \%$, assessment and evaluation of learning vocational education $7 \%$, the motivation to learn and motivation to choose vocational education by $7 \%$, information education $6 \%$, the performance of teachers of vocational education $3 \%$, curriculum development $2 \%$, industry's role to the vocational education $1 \%$ and $0.29 \%$ policy.

Trends in the number of vocational education-related research is shown in Figure 3. judging from the span of ten years (between: 2007-2016), the amount of research carried out has increased. The findings are a sign that efforts to realize the role of vocational education as a major source of development of a nation has a positive trend.

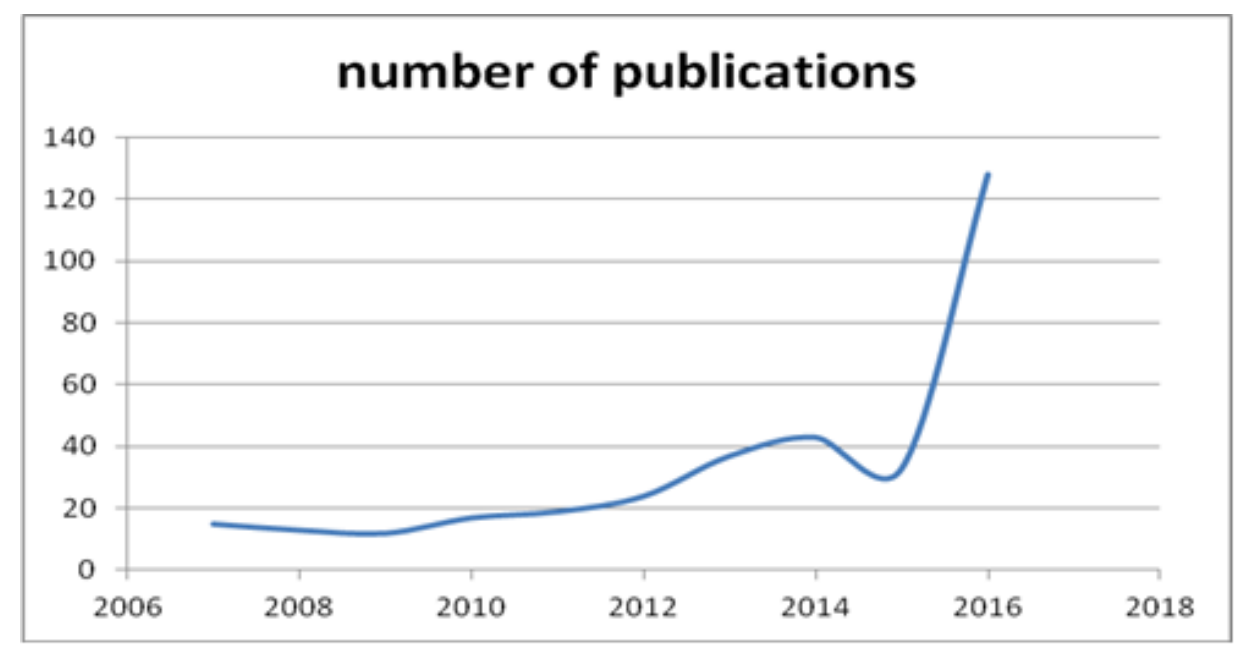

Figure 3. Trend of Vocational Education Research

\section{Conclusion}

This article presents the results of a study of aspects and direction of development of vocational education research. Based on the results of the study, it was found twelve aspects that exist in vocational education, the model of learning, instructional media, instructional materials, other studies related to vocational education, competence of graduates, assessment and evaluation of learning, motivation to learn, educational information, the performance of teachers, development curriculum, the role of industry and vocational education policy. Publication of data searches have been conducted to determine the direction of the development of vocational education research. Judging from its aspects, aspects of the development of the learning model is still the focus of research scientists.

\section{References}

Agrawal, T. (2013). Vocational Educational and Training Programs (VET): an Asia perspective. Asia Pasific Journal of Cooperative Educatioan, 14(1), 15-26.

Asnawi, R., and Djamiko, I. W. (2015). A Challenge of Vocational Education for Preparing Green Employment, 2(20), 175-178.

Kharistiani, E. And Ariwibowo. (2013). Geographic Information Systtem of Web-Based SMA/Vocational School Mapping (Case Study: Kebumen District). Journal of Informatics Engineering. (1). 1-9. Doi:http//dx.doi.org/10.12928/jstie.v2i1.2600. 
Djohar, A. (2007). Technology and Vocational Education. Applications in Science and Education. Bandung: Pedagogiana Press. (1), 1285-1300.

Fuller, A. (2015). Vocational Education. Second Edition. International Encyclopedia of the Social \& Behavioral Sciences. 25(9), 232-238. doi: 10.1016 / B978-0-08-097086-8.92091-9.

Kasnar, A. and Santoso, E. B. (2009). Development of Senior High Schools Based on Industrial Sector Requirements In The Southern Gresik Area. National Journal of Spatial Planning. 4(1), 10-24.

Mortaki, S. (2012). The Contribution of Vocational Education and Training in the Preservation and Diffusion of Cultural Heritage in Greece: The Case of the Specialty Guardian of Museums and Archaeological Sites. International Journal of Humanities and Social Science. 2(24), 51-58.

Paryono. (2013). Mapping national and regional TVET initiatives in Southeast Asia and beyond in response to students and labor mobility. TVET@Asia, (1), 1-8. Available at: http://www.tvet-online.asia/issue1/paryono_tvet1.pdf.

Tykli, L. (2015). Reconceptualizing TVET and development: a human capability and social justice approach. Revisting Global Trends in TVET, (1), 3-33.

Wijanarka, B. S. (2014). Government policy on development of vocational and vocational Ideal. National Journal of Technology and vocational education. 21(4), 1-10.

Yasin, R. M. et. al. (2013). Current trends in technical and vocational education research: A metaanalysis. Asian Social Science, 9(13), 243-251. doi: 10.5539/ass.v9n13p243. 